\title{
Patrizia Cordin
}

\section{Germanic place names spread throughout Trentino}

\author{
A research in the database of Dizionario toponomastico \\ trentino
}

Abstract: Romance and Germanic linguistic varieties have co-existed in Trentino since the Middle Age, when some Southern Bavarian groups moved to this territory and settled down in the area between Lavarone and Asiago and in Fersental. Nowadays, two German varieties (Cimbrian and Mòcheno) are spoken in a few villages and numerous Germanic place names are attested in the areas close to these municipalities. While much attention has been paid to these toponyms, Germanic place names attested in other areas of Trentino have not been inquired.

This paper aims to present the findings of a research investigating the latter category of Germanic place names. The inquiry was conducted with the help of the online DTT (Dizionario Toponomastico Trentino) database focusing on a specific domain, i.e. some Germanic loanwords that are used in the Trentino dialect and refer to ground morphology.

The results show that several hundreds of place names with a Germanic origin are spread in the whole province. These toponyms entered Trentino dialects from German and Tyrolean varieties during different periods, and propagated in the area especially during the XIX century under the Hapsburg government.

\section{Introduction}

Romance and Germanic languages have co-existed in Trentino for centuries. Several linguistic varieties are traditionally spoken in the province: (i) so-called 'Trentino', which is the shorthand for many varieties used in the area and belonging to Lombard-Venetian dialects, (ii) Ladin, a Romance minority language spoken in Fassa Valley near the Dolomites; (iii, iv) Cimbrian and Mòcheno (Fersentalerisch), two German minority languages spoken in two different areas of Trentino since the Middle Age (ca. 12th Century), when Southern Bavarian groups moved to this territory and settled down in the area between Lava-

Ә Open Access. (c) 2018 Patrizia Cordin, publiziert von De Gruyter. (cc) BY-NC-ND Dieses Werk ist lizenziert unter der Creative Commons Attribution-NonCommercial-NoDerivatives 4.0 Lizenz.

https://doi.org/10.1515/9783110601268-002 
rone and Asiago and in Fersental. ${ }^{1}$ Nowadays, the two German varieties are spoken only in few villages (Cimbrian in Luserna/Lusérn, Mòcheno in Palai en Bersntol/Palù del Fersina, Garait/Frassilongo, Vlarotz/Fierozzo), but numerous linguistic traces of the ancient German settlements are attested in some wider areas close to these municipalities. The most evident signals of the presence of ancient groups of inhabitants are place names. Many of these toponyms are illustrated in different studies published over the last eighty years.

In this article, though, I inquire whether Germanic place names exist in Trentino territories other than those shown in figure 1, where German populations settled during the Middle Age. The description of my research and its findings is articulated in three parts. In the first section I show a map of Trentino territories that were inhabited by German communities in the Middle Age. Then I provide some examples of the most frequent German place names attested in those areas. In the second section I present the Dizionario Toponomastico Trentino - DTT (Trentino Toponymy Dictionary) and, in particular, its online database, ${ }^{2}$ which represents a powerful tool for all researches on Trentino place names. The online DTT also constituted a significant support for the specific inquiry that I present in the third and last section. In $\S 3$, after introducing the criteria that I adopted for my search, I present the main results achieved using a given set of Germanic loanwords that refer to ground morphology and that were commonly used (at least until fifty years ago) in Trentino dialects. Notably, such words have been also used as toponyms and are attested in many areas of the province. The results suggest that toponyms with a Germanic origin attested in areas other than Cimbrian and Mòcheno ones do not come directly from German. Rather, they are formed with words that entered the Trentino dialect from German and Tyrolean during different periods and that spread out in the dialects spoken in the province especially during the XIX century under the Hapsburg government.

\section{Previous studies on Germanic place names in Trentino}

So far, studies regarding German toponyms in Trentino have focused on those areas where German settlements were situated in the past. A 1988 work by

1 See Pellegrini (1977); Bidese (2010); Rowley (1986).

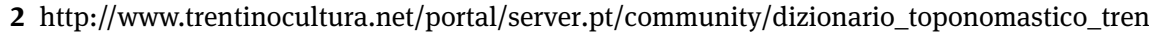
tino 
Giulia Mastrelli Anzilotti illustrates the distribution of these toponyms within the Trentino province. The author highlights the scarcity of Germanic toponyms in Western Trentino, where only a few traces remain in the upper part of Non Valley, in the area of Andalo near Trento and, finally, in the municipality of Garniga at the bottom of Mount Bondone. ${ }^{3}$ In the first case, toponyms with Germanic origin can be explained by the proximity with German-speaking or multilingual areas in Alto Adige; in the second case, by the existence of an ancient (14th-century) German settlement; in the third case, by the presence of miners and farmers who came from Bavaria in the 13th century according to the will of the bishop of Trento.

On the contrary, traces of old German settlements are widely attested in place names of Eastern Trentino, where two groups of population coming from Germany settled in the past: the Cimbrian one, to be found on the tablelands between the Adige and the Brenta, precisely in Folgaria, ${ }^{4}$ Noriglio, Ronchi di Ala, Terragnolo, Trambileno, Vallarsa, ${ }^{5}$ Lavarone $^{6}$ and Luserna; and the Mòcheno one, situated in the area of Pergine, ${ }^{7}$ in Vignola, above Caldonazzo lake, ${ }^{8}$ in Castagné, and in mountain houses scattered around the mount of Roncegno ${ }^{9}$ as well as in the area of Piné. ${ }^{10}$ An overview of German settlements in Trentino is provided on the map in figure 1.

A great deal of toponyms in Western Trentino has Tyrolean origin and refers to some properties of the land and to its use (Bis Germ. Wiese, Tyr. wise 'meadow', Bìsele 'little meadow', Greut Germ. geraut, Tyr. gereut 'ploughed terrain', Làite Tyr. laite 'slopes', Firòsta Tyr. fihrast 'pasture', Stonàcher Tyr. stoanache 'stone space', Grossém Tyr. groas eme 'large flat ground'). ${ }^{11}$ Other toponyms referring to mountain houses maintain the owners' Germanic surnames (Reiter, Clamer, Nèser, Puller, Pèrgher). ${ }^{12}$ In Garniga, a village not far from Trento, some names attest the ancient presence of miners (Val dei Séchi Germ. Zeche 'mine valley'). ${ }^{13}$

3 Battisti (1971); Mastrelli Anzilotti (1979); Bonatti (1982).

4 Melchiori (1997-98).

5 Flöss (2009).

6 Paternoster (1996-97); Zambelli (1996-97); Battisti (1972).

7 Lorenzi (1930).

8 Brida \& Mastrelli Anzilotti (1981); Flöss (2002).

9 Mastrelli Anzilotti (1998).

10 Gerola (1932); Flöss (2014).

11 All toponyms mentioned in this section and in $\S 3$ are transcribed according to DTT norms. Tyrolean terms quoted in this section are reported from Schatz (1993).

12 Mastrelli Anzilotti (1988).

13 In 1242 the Beseno family called some people from Bavaria to work in the mine that the family owned; Mastrelli Anzilotti (1988) 32. 


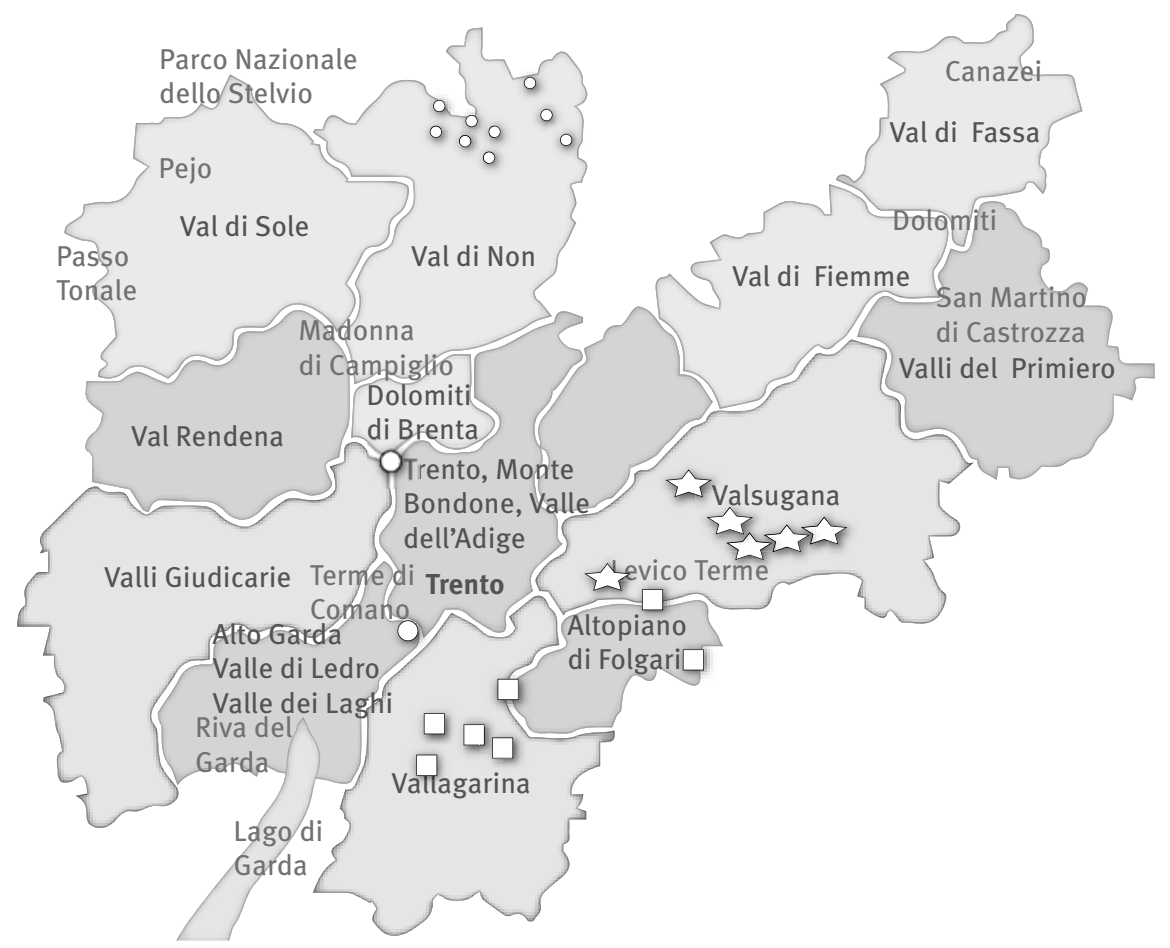

Fig. 1: $O$ isolated German settlements $\square$ Cimbrian settlements לํ Mòcheno settlements.

In Eastern Trentino both Cimbrian and Mòcheno toponyms are numerous. Among them, it is possible to identify some semantic groups that present more occurrences than others, namely:

- names that refer to the shape or territorial characteristics of the land, such as Laita/Làita Tyr. lait 'slope', Gronlait 'wide slope', Pèrch Germ. Berg 'mountain', Bilbom Germ. Wildboden 'wild land', Eck/Éch Germ. Eck, 'bump', Pléz Germ. Platz 'flat land', Lóca Germ. Loch 'hole';

- names that refer to the use of the land, such as: Bis Germ. Wiese 'meadow', Ròsta Germ. Rast, Tyr. rost 'pasture', Raut/Ràut Germ. geraut 'ploughed terrain', Valt Germ. Wald 'wood';

- names that refer to mountain houses (often named after the surname of the owners): Pinter, Plancher, Marter, Stàuderi, Tonézzeri, Sàdleri, Pàcheri, Paldàuf;

- names that refer to activities: Bàlneri Germ. Waldner 'woodsmen', Canèp Germ. Knapp 'miner', Chéserle Germ. Käser 'dairyman';

- names that refer to plants: Poeche Germ. Büche 'beech', Oachlait Germ. Eiche 'oaks' slope, Érla Germ. Erle 'alder', Piràcher Germ. Birn(baum)acker 
'pear tree meadow', Fórelait Germ. Föhrelait 'spruces' slope', Lérch Germ. Lärche 'larch'.

Tyrolean place names from Non Valley as well as of Andalo - in Western Trentino -, the Mòcheno place names of Frassilongo/Garait, Palù/Palai en Bersntol, Fierozzo/Vlarotz, Baselga di Piné, Bedollo, Caldonazzo, Roncegno, and the Cimbrian place names of Lavarone, Terragnolo, Vallarsa - in Eastern Trentino - are all recorded in the online DTT. Thanks to this database it is possible not only to verify their location, distribution, and forms, but also to extend the search to the whole province. In this way, one can determine the presence of a given set of toponyms outside the areas that were traditionally research object of studies on toponymy with German origin.

\section{Dizionario Toponomastico Trentino}

With the province law 16/1987 - Disciplina della toponomastica - the Province of Trento formally started the project of the Trentino Toponymy Dictionary ( Dizionario Toponomastico Trentino - DTT), thereby acknowledging toponyms as immaterial cultural goods that have to be protected and valorized. ${ }^{14}$ The management of the project was entrusted to the Cultural Heritage Superintendence, and precisely to the service named Servizio beni librari e archivistici della Provincia di Trento (Archival and Book Heritage Office and Provincial Archive). The office was supported by a commission for toponymy, an advisory agency that expresses opinions about any issues in the field.

The conception of the project actually began in 1982, when a wide toponymy research program, articulated in three complementary and distinct phases, was conceived. The first phase consisted in a field research (called 'geographic') to the purpose of collecting the names of all Trentino municipalities in a very detailed manner thanks to researchers and local informers. The second phase should comprise a so-called 'historical' research, based on systematic

14 By acknowledging toponyms as cultural heritage that has to be safeguarded insofar as toponyms are elements of memory preservation and tools for completing the culture of a certain area, the Province of Trento anticipated the 2nd article of the Convention pour la sauvegarde du patrimoine culturel immatériel (Paris, 17 October 2003) which sounds "Ce patrimoine culturel immatériel, transmis de génération en génération, est recréé en permanence par le communautés et groupes en fonction de leur milieu, de leur interaction avec la nature et de leur histoire, et leur procure un sentiment d'identité et de continuité, contribuant ainsi à promouvoir le respect de la diversité culturelle et la créativité humaine”. 
scrutiny of archival documents in order to trace back the different forms taken up by place names over time. In the third phase, finally, the 'etymological' research concerning Trentino toponyms should take place, building upon the massive corpus created via field research and archival work. The order of the three phases (geographical, historical, etymological) was strongly motivated by the urgency of collecting oral data, which is only possible thanks to the presence of people who know the territory and remember its names.

The geographical research began in 1987 and ended in 2007. During those two decades, in the 223 municipalities of the Province of Trento ${ }^{15} 180$ researchers collected a total of 205.687 toponyms referring to 158.472 places $^{16}$. Only $20 \%$ of those names were actually present in the cartography, while the remaining $80 \%$ were retrieved from oral tradition. The data collection was completed with audio-recordings of all place names as pronounced by local speakers and with the cataloguing of all toponyms according to established criteria.

The data sheet where each place name is registered is organized with several fields, which had to be filled in by the researcher. First, the transcription of the name in its dialectal form is shown according to a double transcription system (simplified and phonetic); ${ }^{17}$ the cartographic writing also appears on the data sheet if the toponym is recorded on a map. Moreover, the data sheet presents: a geographical indicator that refers to the collected toponym (i.e. a term that synthetically expresses the main geographical characteristic of the place - meadow, rill, path, creek, bridge, orchard, mountain top, pass, soil cavity, ruins, and so forth); a brief description of the place, indicating the altitude, extension, vegetation, relevant properties of the soil and possible references to other toponyms; geographical coordinates for positioning the toponym on the General Topographic Trentino Map (Carta Topografica Generale del Trentino - CTG); other cartographic references, ${ }^{18}$ when available; possible

15 This was the number of Trentino municipalities when the toponym search was carried out. Currently (September 2016) Trentino municipalities are 178.

16 The numerical difference between toponyms and places derives from the fact that several names have one or more variations.

17 To spare the average reader difficulties in reading, phonetic transcription norms within the data sheets of DTT do not coincide with those of IPA transcription. The rules on which the phonetic transcription used in the DTT is based are described at the beginning of each published volume in the series and on the DTT's website.

18 For cartographical references the following sources were used: the General Topographic Map of the Autonomous Province of Trento (Carta Topografica Generale della Provincia Autonoma di Trento - CTG; scale 1:10.000), the maps of the Military Geographical Institute (Istituto Geografico Militare - IGM; scale 1:25.000), Kompass tourist maps (scale 1:50.000), cadastral maps of the territory, the royal registers of the Estate book and maps of the economic forestal and pastoral plan. 
variations of the toponym; the initials of the informers' names. Optional notes, namely relevant observations that were either collected by the informers or by the researcher themselves or inserted while revising the material and bibliographical references complete the data sheet.

The majority of the toponyms is also recorded in an online database which is accessible for public consultation and is constantly updated. ${ }^{19}$ In the electronic database it is possible to carry out searches focused on one or more municipalities or on one or more toponyms. It is also possible to differently combine the search items for advanced search. ${ }^{20}$

A minor, yet relevant part of the catalogue of indexed place names has been published in the book series Ricerca geografica - DTT (Geographical research - DTT). Sixteen publications have been issued so far (September 2016). They regard 56 Trentino municipalities, for a total of more than 40.000 toponyms. Each volume is illustrated with several photos and completed by cartography (namely the CTG indicating the places to which the names presented in the volume refer).

In 2005 the second phase of the DTT project started. This historical phase, which should culminate in the Ancient Toponymy Dictionary (Dizionario Toponomastico Antico - DTA), consists in researching place names in written sources from the $13^{\text {th }}$ until the $19^{\text {th }}$ century. The wide range of documents to be researched includes real estate registries, registers, valuations, urbari, notary deeds, parchments. ${ }^{21}$ Since only some of these documents are printed, several competences are required for the researchers to record historical toponymy data: besides linguistic skills and knowledge about the local territory, historical and paleo-graphical competences are needed.

19 On the $30^{\text {th }}$ of September 2016 data sheets related to 153.000 places (more than 200.000 toponyms) were available online.

20 From the online data sheet, one can select the elements to be searched, namely: the municipality to which the toponym/toponyms belongs/belong; the toponym/toponyms; the geographical indicator, that is the name referring to the main geographical characteristic of the place (meadow, forest, field, etc.); the cartographic sources from which the toponym comes. Each item can be combined with the others. As far as the information collected during field investigations is concerned, the online search cannot be used to explore it. Therefore it is not possible to initiate an online search in the field named 'notes'. In the electronic version of the dictionary this field is absent both as search field and as field visualized within each data sheet.

21 The Teresian cadastre (Catasto teresiano) deserves special attention due to its development over time and its systematic coverage of the territory in the Trentino province; see Bonazza (2004). 
So far (September 2016), investigations have led to the recovery of historical toponyms in documents from different areas and different ages. ${ }^{22}$ In the first research decade almost 60.000 toponymy forms have been recorded. They amount to around 35.000 historical forms, out of which slightly less than the half corresponds to the modern forms indexed in the DTT. ${ }^{23}$ The historical places to which the names refer are around 20.000 (out of which more than 6.000 are coupled with toponymy data sheets in the DTT).$^{24}$ The results of the DTA are not accessible for public consultation yet, but the project envisages putting the collected data online.

The last phase of the project, devoted to the etymological research of Trentino toponyms, will begin only when a significant collection of historical data from written sources will be available besides the enormous amount of data synchronously collected on the field. Data from historical written sources should show the evolution of a certain name throughout the centuries, so that the etymological analysis will be based on sound testimonies concerning the transformation of names over time and space.

\section{A new research in the DTT database}

As already mentioned in $\S 2$, multiple researches regarding place names in Trentino can be carried out by means of the online database of DTT. The purpose of the inquiry that I present in this chapter is to identify toponyms with Germanic origin outside those areas that are still inhabited or had been inhabited for centuries in the past by German speaking communities. The research was motivated by four main questions:

- Are there toponyms with Germanic origin that are spread in the whole province (Trentino)?

- How many are they?

22 Several documents from the archives of Trento, Val di Sole, Alto Garda, Ledro, Primiero, lower Non Valley, Valsugana, Cembra Valley and the Giudicarie have already been investigated.

23 In the DTA data sheet, the oldest form is recorded for each name. Additionally, all found variations are indicated. The document where the word was found is also indicated (according to the coding of the Historical Trentino Archive - Archivio Storico Trentino) as well as the year of the document, its language, the geographical indicator to which the name refers, and, possibly, any reference to a modern toponym.

24 The data on DTA are reported from the presentation carried out by Lydia Flöss at the Provincial Archive of Trento (Archivio provinciale di Trento) on the 23rd of April 2015. 


\section{Ricerca avanzata}

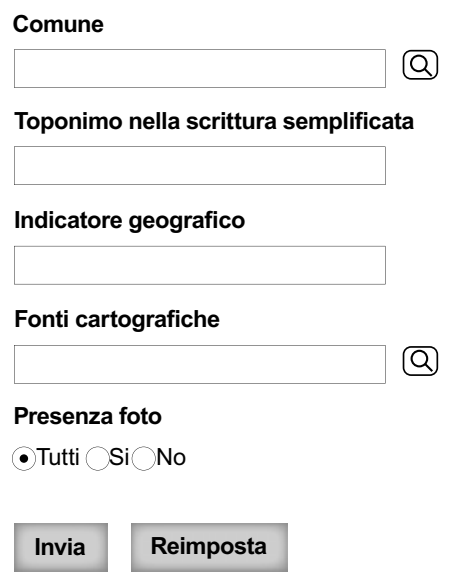

Fig. 2: DTT fields for advanced researches.

- In which areas can they be found?

- Do particularly productive semantic groups emerge?

On the basis of the work done so far, I was able to answer the first question, but I could only find partial answers to the following three. As a matter of fact, this is still a preliminary inquiry focusing on a limited group of toponyms, which were chosen according to precise criteria.

In figure 2 it is possible to see how searches are set up in the DTT database. In my inquiry, all municipalities included in the database as of the 30th of August 2016 were selected. No geographical indicator was included nor cartographic sources were indicated. In the field named 'toponimo nella scrittura semplificata' ('toponym in simplified writing') ten different forms were put in (see table 1). The hypothesis that guided the selection of such forms is that words of other languages more easily become part of the toponymy of the whole territory if they are already assimilated in the dialectal lexicon. Therefore, in order to choose the toponym sample to be searched, I first obtained a list of words attested as loans from German in the ALTR (2005), the electronic archive gathering five Trentino lexicons. ${ }^{25}$ The search result indicated 322 items. Among them, I selected terms pertaining to a semantic domain that is particularly relevant to toponymy, namely names used to describe the shape and the

25 Aneggi (1984); Groff (1955); Prati (1960); Quaresima (1964); Tissot (1976). 
characteristics of the land. ${ }^{26}$ I compared this list of words with the lists of Trentino dialectal terms having a Germanic origin - Langobardic, Bavarian or Tyrolese - that are published in the main studies on the topic. ${ }^{27}$

The overview of the results is shown in table $1 .^{28}$ The first column lists the different forms inserted in the DTT field 'toponym in simplified writing'. They are written without any accents and are marked with an asterisk at the end, ${ }^{29}$ that makes it easy to find all occurrences of a certain form in toponyms containing it, no matter what accent or word ending (singular or plural suffix, masculine or feminine suffix, derivational or altered suffix, or compounding with another word).$^{30}$ The second column reports the total number of occurrences attested in all municipalities, including the German-speaking ones. The third column refers to the figures that illustrate the distribution of different

26 Dialectal loans from German and Tyrolean pertaining to other semantic groups could represent an interesting object for future research. Relevant to toponymy, for instance, are the domain of zoonyms and that of ethnic epithets. Among zoonyms, the following loans from German are listed in the ALTR: bòc $\lesssim$ Bock 'billy goat', càuzza $\lesssim$ Kauz 'owl', crosnòbol Kraizschnabel 'crossbill'; cròt $\lesssim$ Kröte 'toad'; finch $\lesssim$ Fink 'chaffinch'; ròz $\lesssim$ Ross 'nag'; tòla Dohle 'crow'; pàit $\lesssim$ Paita 'turkey' (for the latter term Quaresima 1964 suggests a Langobardic origin). Among ethnic names, the following words are recorded as loans from German in the ALTR: bòlder 'German (neg.)'; mòchen 'from Val dei Mòcheni, from mountain houses'; tóderlo 'Tyrolean'; tòic 'German'; zigàiner 'gypsy'. A third domain that could deserve further attention is represented by German family names, widespread on the whole province, as names of places.

27 Del Murero (1890); Schmid \& Vigolo (1998); Valduga (2000-01). See Morlicchio (1989) and Zolli (1986) for a comparison with German loanwords attested in Italian.

28 Two names, scòfa and sgrèben, that are reported in ALTR (2005) as German loanwords, have not been inserted in table 1, because of their uncertain origin. Scòfa is reported by Tissot (1976) with the meaning of 'prato ripido, dal ted. Schupfen' ("steep meadow from German Schupfen"). In DTT one finds 48 toponyms originated from this form, mostly in Primiero area. Groff (1955) attests Sgrèben with the meaning of 'stony, sterile field'; Quaresima (1964) provides the meaning of 'dry terrain' and derives the word from the Slovenian grebben 'roccia (nel mare)' 'rock (in the sea)'. Del Murero (1890) proposes a different origin: he connects the word sgreben to the German verb graben 'scavare'. 11 toponyms containing sgrèben are attested in the DTT.

29 The inflected words stol/stoi and tom/tomo/tomi were inserted for the search in the online $D T T$, being the uninflected forms stol ${ }^{\star}$ and tom* the initial sequences for a very large number of place names.

30 The inserted form is also recognized as a part of a noun phrase. When the searched form was also found in toponyms that do not have German origin because of the overlapping of the searched phonetic sequence with a same sequence that is present in other words, all irrelevant occurrences were not taken into account. 
Tab. 1: German forms for geo-toponyms spread in the whole province.

\begin{tabular}{|c|c|c|c|c|}
\hline $\begin{array}{l}\text { forms used } \\
\text { for the research } \\
\text { in DTT }\end{array}$ & $\begin{array}{l}\text { occurren- } \\
\text { ces }\end{array}$ & areas $^{31}$ & $\begin{array}{l}\text { geographic } \\
\text { indicators }\end{array}$ & sources \\
\hline lait $^{\star}$ & 315 & see fig. 3 & path, slope & $\begin{array}{l}\text { laita } \\
\text { Aneggi: costa dirupata 'slope'; } \\
\text { Tissot: sentiero 'path' }\end{array}$ \\
\hline $10 c^{*}$ & $199^{32}$ & see fig. 4 & hole & $\begin{array}{l}\text { loca } \\
\text { Groff, Tissot, Aneggi: fango, poz- } \\
\text { zanghera 'mud, puddle'; } \\
\text { Tissot, Aneggi: pozza 'puddle'; } \\
\text { locia } \\
\text { Quaresima: fango 'mud' }\end{array}$ \\
\hline raut*$^{\star} /$ raot $^{*}$ & $215 / 22$ & $\begin{array}{l}\text { see fig. } \\
5 a / 5 b\end{array}$ & field & $\begin{array}{l}\text { raut } \\
\text { Quaresima: novale 'new field' }\end{array}$ \\
\hline rost* & 155 & see fig. 6 & bank & $\begin{array}{l}\text { ròsta } \\
\text { Quaresima: rosta, argine; briglia } \\
\text { 'bank' } \\
\text { Groff: argine 'bank' }\end{array}$ \\
\hline stol/stoi & $88 / 54$ & $\begin{array}{l}\text { see fig. } \\
7 a / 7 b\end{array}$ & $\begin{array}{l}\text { tunnel/ } \\
\text { tunnels }\end{array}$ & $\begin{array}{l}\text { stól } \\
\text { Tissot: cunicolo di miniera 'mine } \\
\text { tunnel' }\end{array}$ \\
\hline tom/tomo/tomi & $18 / 9 / 8$ & $\begin{array}{l}\text { see fig. } \\
8 a / 8 b / 8 c\end{array}$ & bank & $\begin{array}{l}\text { tòm } \\
\text { Quaresima: argine 'bank' } \\
\text { tòmo } \\
\text { Groff: terrapieno, araine 'bank' }\end{array}$ \\
\hline
\end{tabular}

toponyms in the areas of Trentino. The fourth column presents the geographical category that identifies the named place. Finally, the last column indicates the lexicographical sources under which words containing the searched form are recorded. Their meaning in Italian and English is also provided.

The first form, lait (<Middle High German lite 'bergabhang, halde' [Lexer]), has the greatest number of occurrences in the entire group. The toponym that contains it appears with singular, plural, masculine and feminine inflections and with altered suffixes; it is mainly used to name meadows and woods that grow on sloping parts of land. I provide here some examples and indicate the

31 All the maps shown in figures (3)-(8) are taken from the online DTT.

32 The total number of occurrences for loc* is 208, but I don't consider nine records, where Loc is the first part of the following place names: Locanda, Locatóri, Locale (twice), Locomotiva, Locréte, Locòvi, Sintéri de la Pró Lòco, Tornante del Lòchmann. 
municipality each of them belongs to: ${ }^{33}$ Laitòla at Valfloriana, Laite del Gianmaria at Mezzolombardo, Laite del Tistòla at Carano, Laite del Töfa at Carano, Laiti at Segonzano, Laita at Daiano, Laita at Sover, Laita dei Rampini at Mezzocorona, Laite at Civezzano, Laite at Capriana, Laite dei Pini at Carano, Laite dei Cansòcoi at Predazzo, Laiton at Castello-Molina di Fiemme, Laiton at Segonzano, Maso Laita at Capriana, Menador de le Laite at Albiano, Pineta dei Laiti at Mezzocorona, Sbàrbol del Laiton ${ }^{34}$ at Castello-Molina di Fiemme, Sintér de la Laita at Lona Lases.

The distribution of this toponym within the province is illustrated in figure (3): the name is mainly present in the Mòcheno area and in the Cimbrian area including the neighbouring territories (the areas of Pergine, Pinè and Rovereto). Beyond these areas, the toponym can mainly be found in Western Trentino, precisely around Trento, in Non Valley, in Cembra Valley and in Fiemme Valley.

The second form, loc (< Middle High German Lôch 'gebüsch' [Lexer], cf. German Loh 'Hain'), has nearly 200 occurrences. Toponyms that contain it refer to meadows, fields, vineyards, fruit gardens, grazing lands. They present different pronunciations, inflections and combinations, as the following examples show: Cap del Lòch at Valdaone, Buse da la lòca at Carano, Loc' at Predaia and at Ton, Löc' da l'aqua at Strembo, Lòca at Sover, Löch at Borgo Chiese, Storo, Trento, Pinzolo, Ledro, Giovo, Carisolo, Lóch at Comano Terme, Segonzano, Pieve di Bono, Lóch del Gioanin at Treville, Loce at Mazzin, Lòch at Trento, Lòch de la cèsa at Lavis, Lòche at Castello-Molina di Fiemme, Dimaro, Castelnuovo, Segonzano, Lòchera at Trento, Lochinèl at Mori, Lóchi at Dimaro, Lòchje at Malé, Locia at Mazzin, Lòcia at Predaia, Locia de Ciamp at Pozza di Fassa, Locia de baranchie at Campitello, Sora la locia at Canazei, Val de le lòche at Segonzano and Lona Lases.

Figure (4) shows that the name is well attested in the Mòcheno area and in the Cimbrian area including the neighbouring territories (the areas of Pergine, Pinè and Rovereto). Beyond these areas, the toponym is recorded both in Eastern Trentino (around Trento, in Cembra Valley, in Fiemme Valley, in Fassa Valley and in Valsugana) and in Western Trentino (in the Giudicarie and in Val del Chiese).

33 To illustrate toponyms deriving from the forms presented in table 1, throughout the text I provide examples that are attested in areas of the province without any (past) stable German settlement.

34 Also Sbàrbol, a name attested in 10 toponyms of Valfloriana and Castello-Molina di Fiemme, seems to derive from Germ. Schwarzwald 'black wood'. 


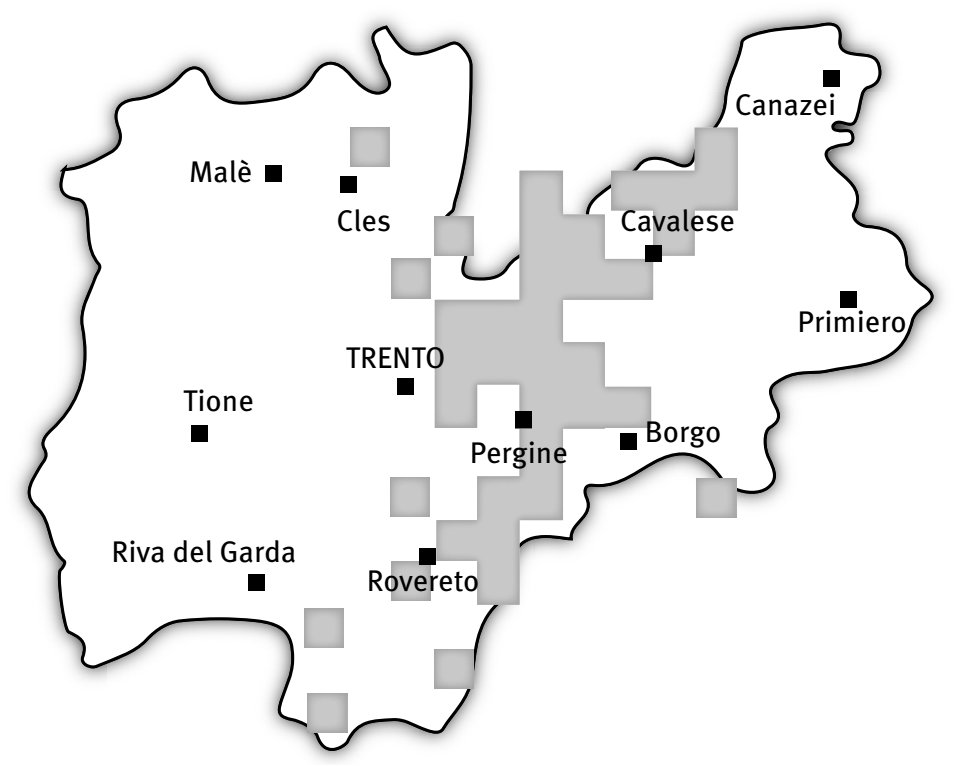

Fig. 3: Toponyms formed with lait.

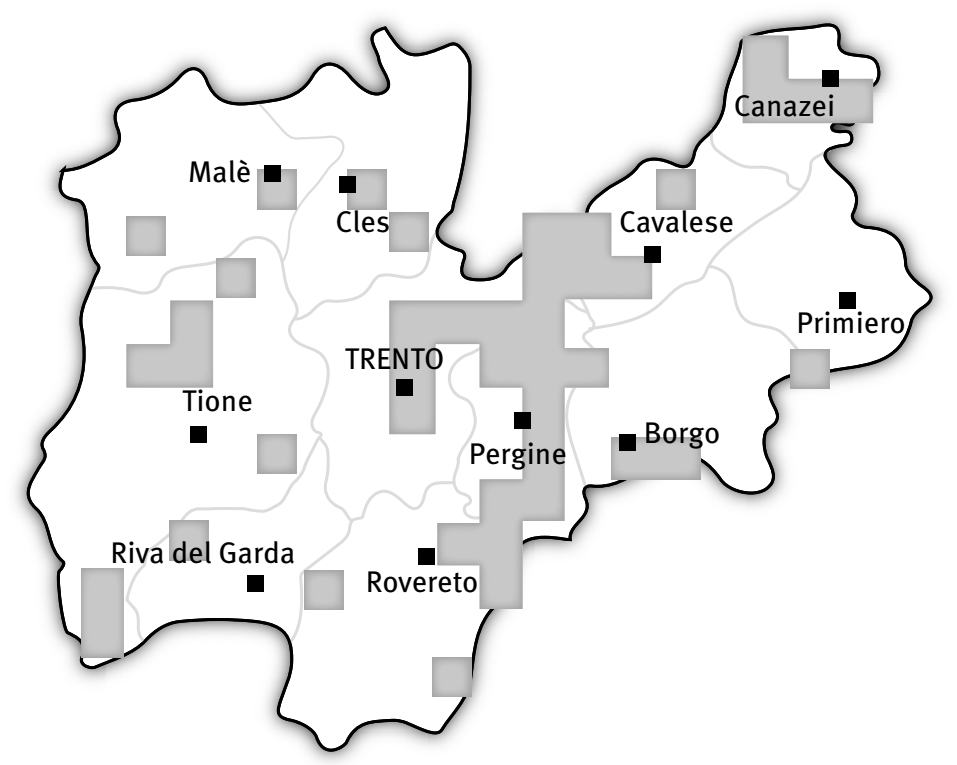

Fig. 4: Toponyms formed with loc. 
Also the forms raut/raot (< Middle High German geraut 'stück land, das durch riuten urbar ist gemacht worden' [Lexer]) can be found in more than 200 toponyms that mainly serve to name fields, vineyards, meadows and wild lands. In the toponyms, often occurring as noun phrases, one finds especially the masculine form (singular and plural), sometimes with a diminutive or an augmentative suffix. Some examples follow: Bugn dei Ràuti at Commezzadura, Capitèl dei Ràuti at Mezzocorona, Mas dei Rauti at Predaia, Bosch del Raut at Soraga, Palù del Ràut at Pellizzano, Pònt del Ràot at Vermiglio, Prè del Raut at Moena, Ràoti at Ossana, Peio, San Michele all'Adige, Raut/Ràut at Canazei, Pozza di Fassa, Vigo di Fassa, Soraga, Castello-Molina di Fiemme, Lavis, Nave San Rocco, Mezzolombardo, Cles, Ville d’Anaunia, Predaia, Mezzana, Pellizzano, Malé, Peio, Raut de l’Àngeli at Mezzocorona, Ràut dei Clementèi at Zambana, Rautèl/Rautel at Commezzadura, Mezzocorona, Ton, Ville d'Anaunia, Rauti/Ràuti at Lavis, Zambana, Giovo, Valfloriana, Fai, Faedo, Cavedago, Cavizzana, Mezzocorona, Mezzolombardo, Roveré della Luna, Predaia, Rabbi, Rauton at Valfloriana, Ràoten at Madruzzo and Cavalese.

As figure (5a) shows, toponyms formed with raut* are concentrated in the Southern areas of Trentino, which were once Cimbrian, and in the area of Pergine. Beyond these territories, this root for place names is mainly attested in Non Valley, Fassa Valley and Fiemme Valley. Figure (5b) shows more sporadic occurrences of names formed with raot*: in contrast with forms with raut*, these toponyms are absent in Southern Trentino and are only partially present in Non Valley.

155 toponyms derive from Rost (< Langobardic *hrausta, 'shelter made of leaves and branches’; also 'barrier' [Gamillscheg 1934-36], Germ. Rost 'grid'). Rosta is an Italian term, ${ }^{35}$ which is mainly used in the Venetan and in the Lombard area. In the Trentino dialect it is attested with the meaning of 'argine' '(river) bank'. Several toponyms that are formed with this root refer to canals, millraces, streams, banks and barriers. However, some mountain crests and sloping meadows are also named Rost, Rosti. In these cases the origin of the toponyms should be different: following Mastrelli Anzilotti 1988, it is supposed to be the Tyrolean dialect rost 'rest', referred to cattle, namely (fih)rost 'pasture'.

The form Rost 'grid', mainly inflected as feminine (singular and plural), can also be found in altered and in phrasal toponyms, as the following examples illustrate: Bóca da ròsta at Tesero and Ziano, Canai de le ròste at Valdaone, Prai da Ròsta at Castelnuovo, Ri de la Ròsta at Cles, Ròst at Comano, Carisolo,

35 Nocentini (2010). 


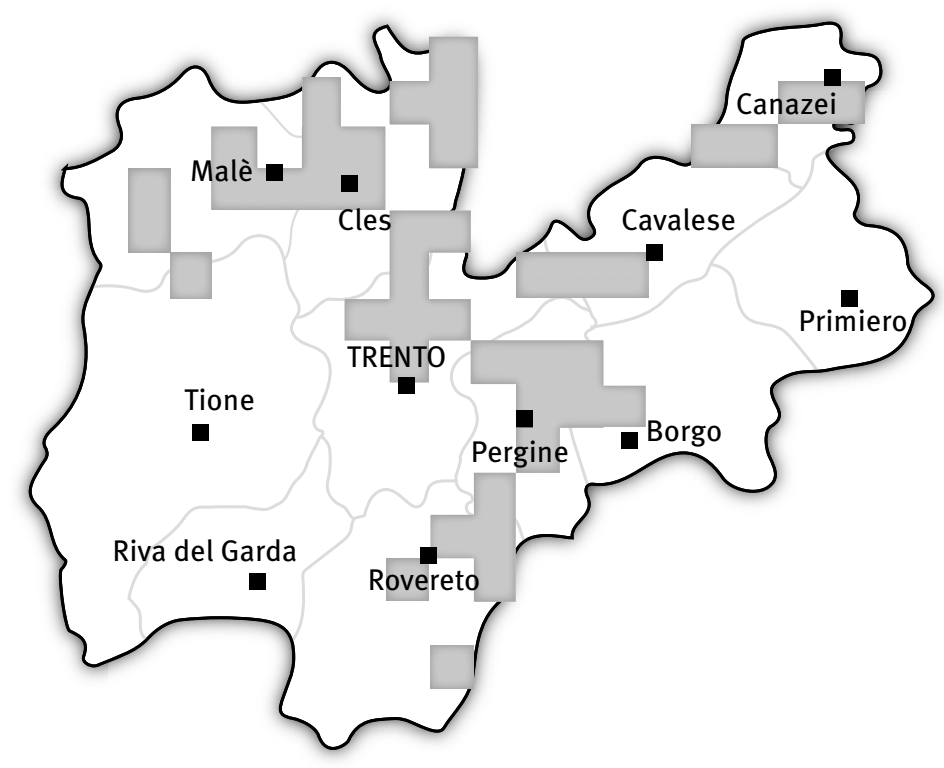

Fig. 5a: Toponyms formed with raut.

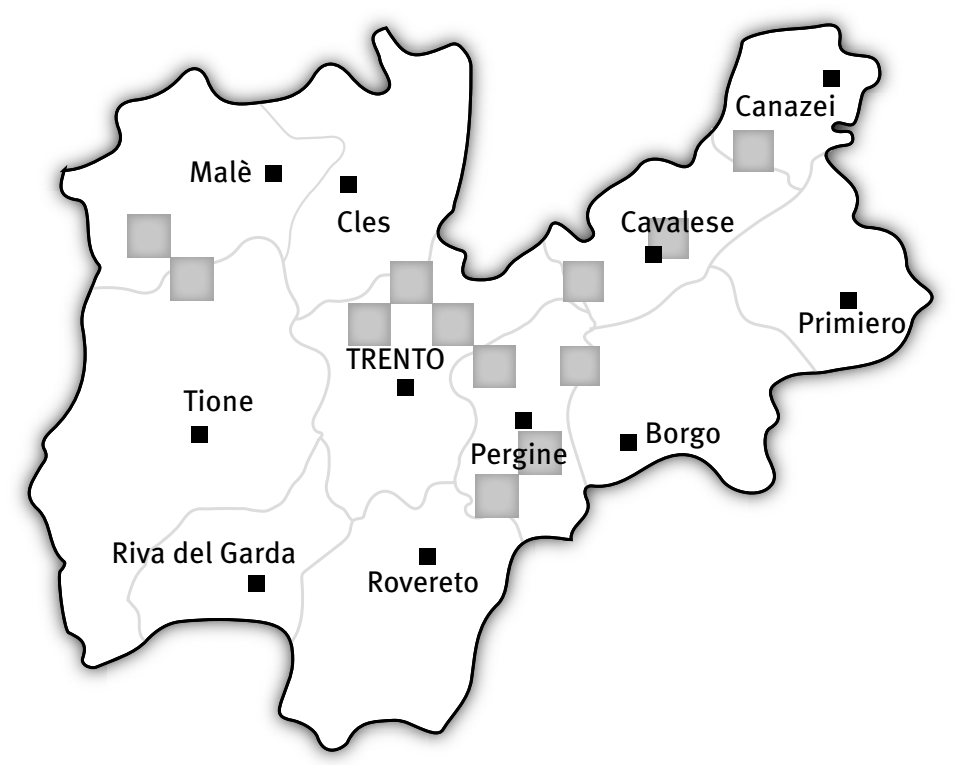

Fig. 5b: Toponyms formed with raot. 


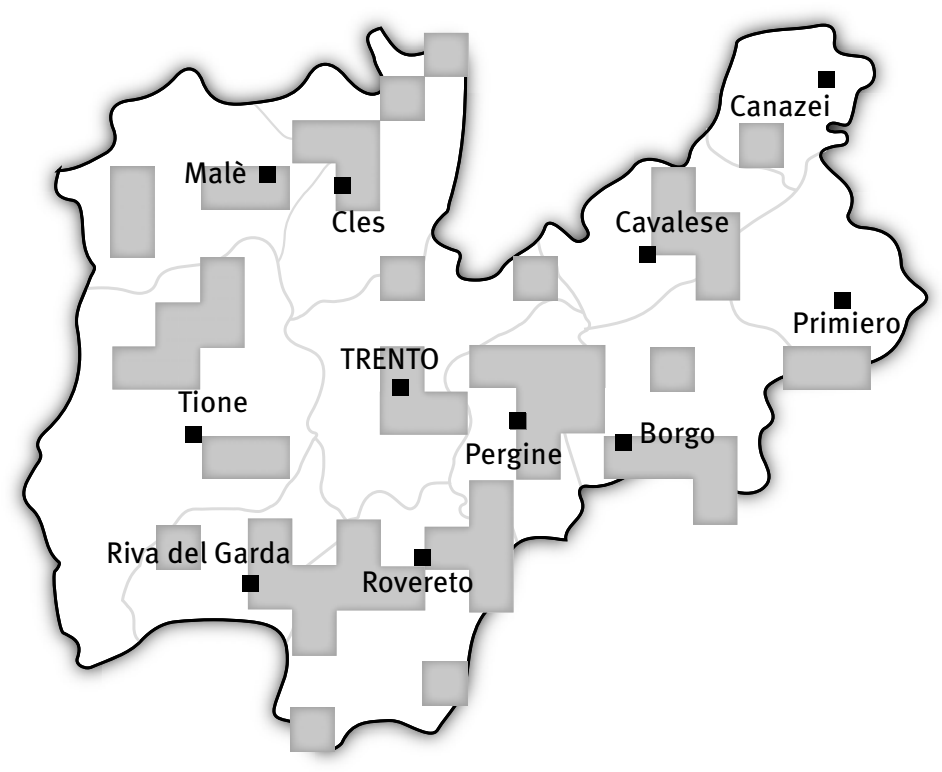

Fig. 6: Toponyms formed with rost.

Castel Ivano, Mezzana, Ròsta at Civezzano, Trento, Isera, Madruzzo, Pinzolo, Spiazzo, Strembo, Panchià, Commezzadura, Predaia, Vermiglio, Castelnuovo, Cinte Tesino, Primiero San Martino di Castrozza, Scurelle, Ròsta de l'Àdes at Trento, Ròsta dei Mulinèri at Grigno, Ròsta dei schirati at Ziano, Ròsta fréda at Borgo Valsugana, Ròste (or Róste or Roste) at Lavis, Mezzocorona, Mezzolombardo, Arco, Nogaredo, Caldes, Dimaro Folgarida, Cembra Lisignago, Grigno, Canal San Bovo, Moena, Rostèla at Lavis.

Figure (6) shows that toponyms with rost* are spread all over the province.

The toponyms Stol/Stoi (< Middle High Geman stolle 'stütze, gestell, pfosten, fuss' [Lexer], cf. German Stollen) indicate caves, galleries, clefts, shelters under a rock and trenches. In the singular form, which is the most widespread, one finds, among others: Stol/Stòl/Stól at Trento, Levico Valsugana, Nomi, Villalagarina, Vallelaghi, Ziano, Panchià, Tesero, Moena, Stól de la Minéra at Canal San Bovo, Stól de le pégore and Stól de le bombe at Mori, Stól de le zinque bóche at Rovereto, Stól del morét at Ronzo Chienis, Stól de la vècia at Primiero San Martino di Castrozza. In the plural form, one finds, among others: Trè Stói at Cinte Tesino and Trento, Dó Stói at Trento, Stoi/Stói at Trento, Besenello, Isera, Nogaredo, Pieve Tesino, Telve, Vermiglio and Pozza di Fassa.

The maps represented in figures (7a) and (7b) show that the distribution of these toponyms is limited to Eastern Trentino (also externally to Cimbrian 


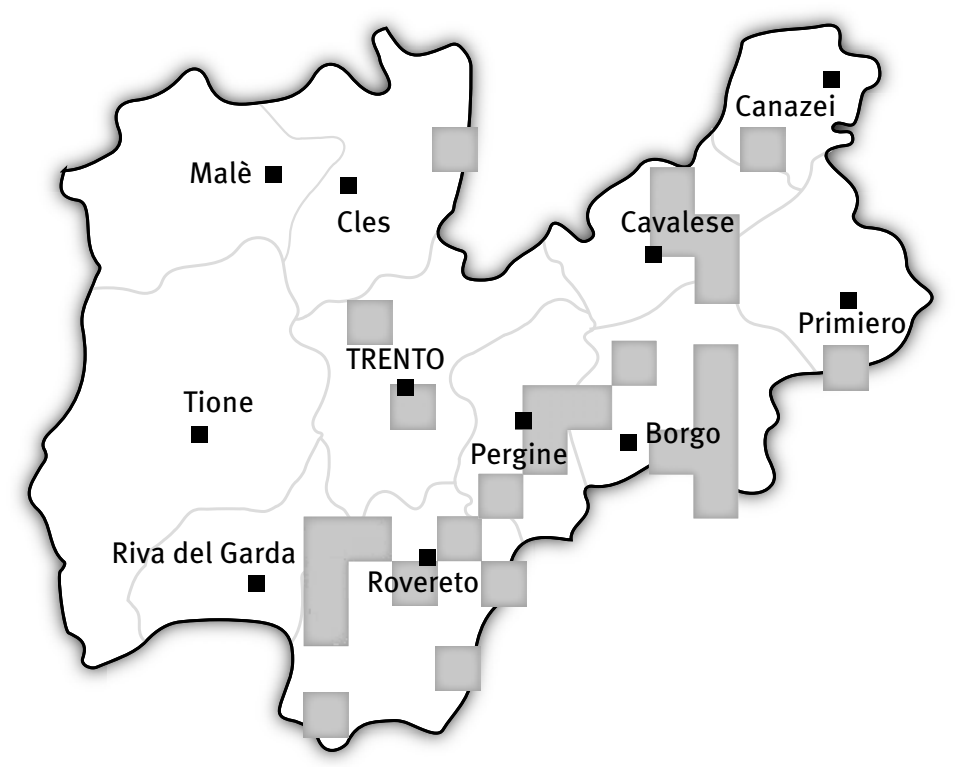

Fig. 7a: Toponyms formed with stol.

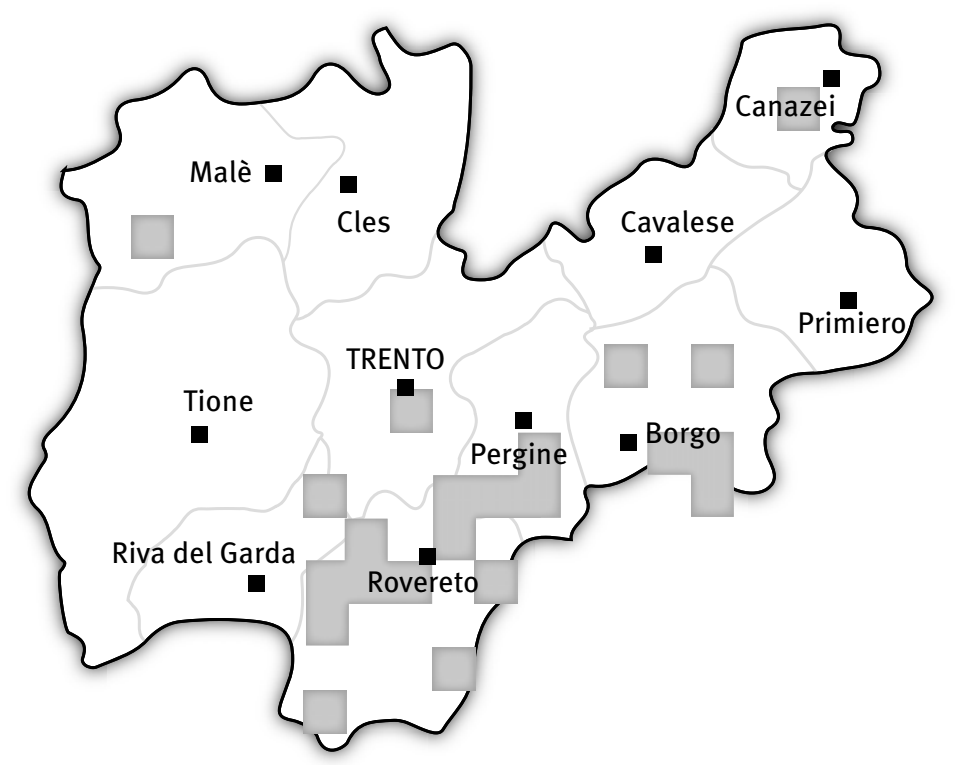

Fig. 7b: Toponyms formed with stoi. 
and Mòcheno areas), with a single exception in Non Valley. The plural form is only sporadicly recorded both in the East and in the West of the Northern part of the province, with greater concentration between Trento and Rovereto, in Valsugana and in Tesino.

The forms Tom/Tomo/Tomi (< Middle High German tam 'damm, deich' [Lexer], cf. German Damm) indicate banks, stonewalls, embankments. The singular form ending with consonant is the most widespread. One finds: Tòm at Trento, Mezzano, Peio, Primiero San Martino di Castrozza, Busa del Tòm at Brentonico, Tòm de la ròsta at Giustino, Tòm de l'Àdes at Nave San Rocco and Lavis, Tòm del Nós at Nave San Rocco, Vècio tòm at Mezzolombardo. The singular form ending with vowel (Tòmo) is present in Non Valley, at Ala and at Comano Terme. The plural Tòmi appears at Trento, Nomi, Pomarolo, Vallelaghi, Villalagarina; Tòmi de l'Àdes at Mezzocorona.

The maps represented in figures $(8 \mathrm{a}, \mathrm{b}, \mathrm{c})$ show the occurrences of the three forms that, although rare, are attested in several areas of Trentino. They are not recorded in the South-Western part of Trentino, in Fassa Valley and in areas with Cimbrian and Mòcheno influence.

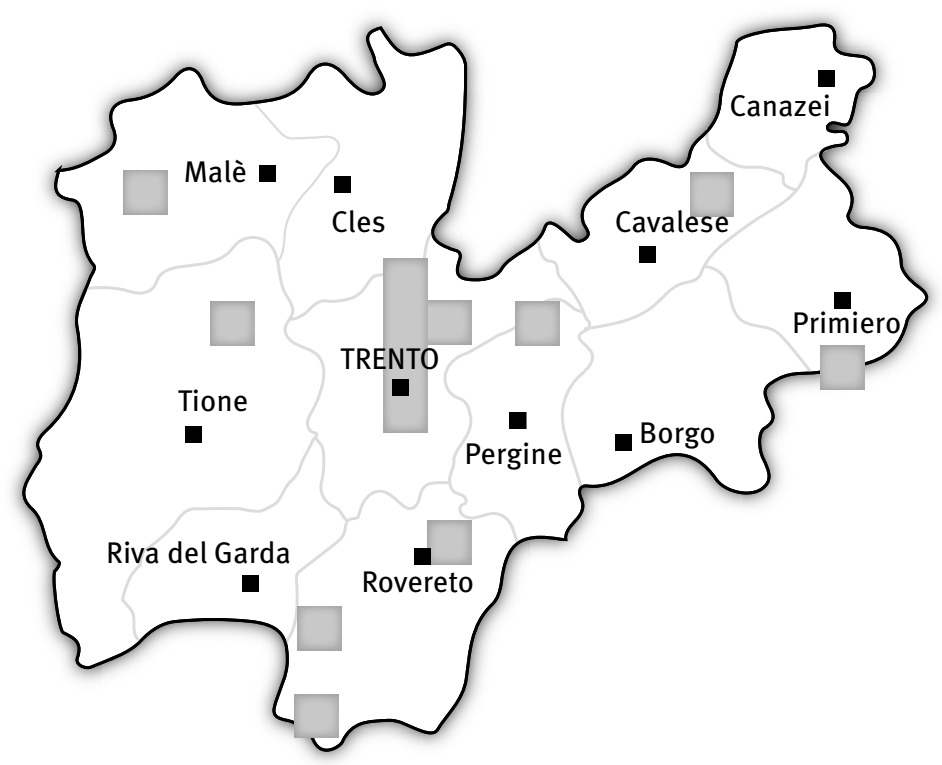

Fig. 8a: Toponyms formed with tom. 


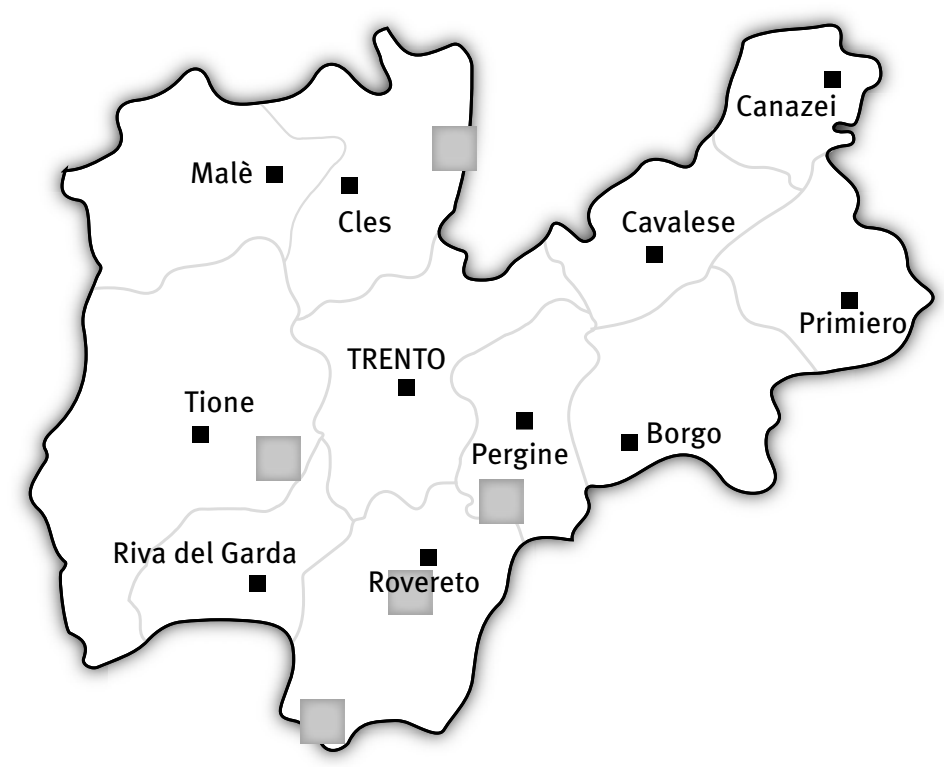

Fig. 8b: Toponyms formed with tomo.

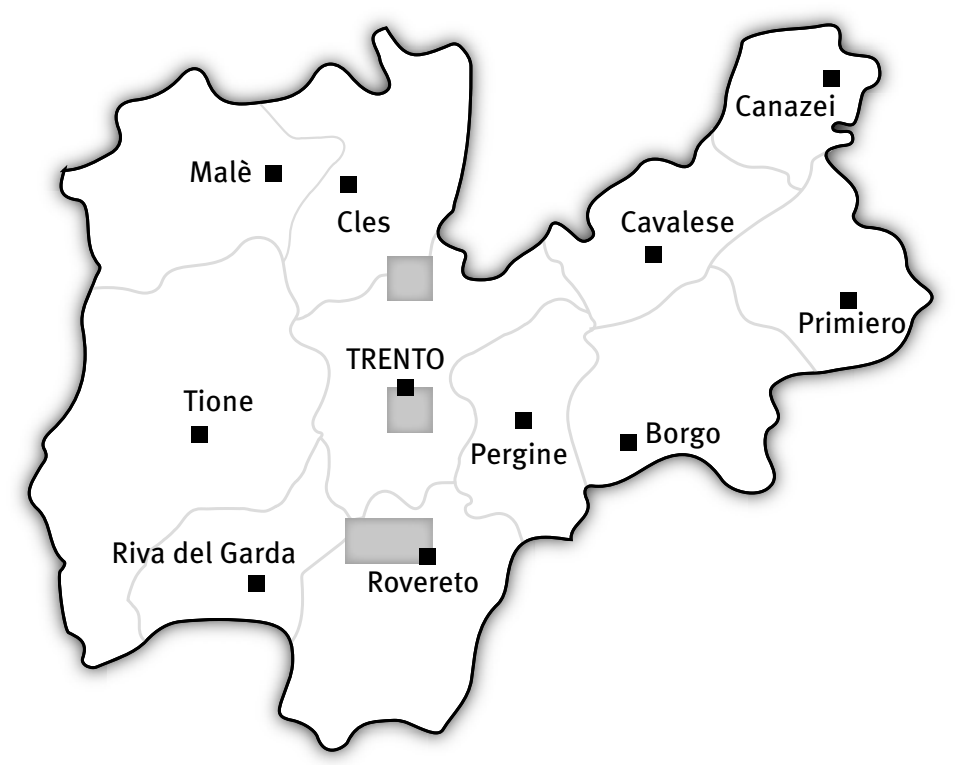

Fig. 8c: Toponyms formed with tomi. 


\section{Concluding remarks}

This inquiry has focused on a specific group of Germanic toponyms, namely place names that refer to some features of the land (geo-toponyms). The specific group was selected among the Germanic loanwords adopted by Trentino dialects that are used to indicate some characteristics of the territory and that are recorded in the ALTR. A following analysis was carried out in the DTT for each selected loanword, in order to find out whether the selected toponyms are present in the province, and, if so, where and in which form(s).

The DTT database provides evidence of the presence of several Germanic toponyms in Trentino in several places outside Cimbrian and Mòcheno areas. These toponyms derive from Langobardic, Bavarian and Tyrolese words that entered in local Romance dialects during different periods. They are attested especially where the contact with a Germanic variety was favoured by the proximity to the border of South Tyrol or to important roads connecting Germanic settlements to other valleys.

Another important source for Germanic loanwords referring to the territory, and for toponyms derived from them, is the relevant engineering activity conducted in Trentino under the Hapsburg government during the XIX century for the construction of roads, bridges and tunnels, and for channelling rivers. This is attested by the spread in the whole province of toponyms formed with rost-, stol, stoi, tom-, tomo, tomi.

Thanks to the DTT database, in future works it will be possible to extend the search conducted on geo-toponyms to other loanwords belonging to different domains that are relevant for toponymy.

\section{References}

ALTR - Archivio lessicale dei dialetti trentini (2005): Cordin P. (ed.). Trento: Dipartimento di Scienze filologiche e storiche.

Aneggi, Aldo (1984): Dizionario cembrano (triangolo Sover - Montesover - Piscine): parole e cose - frasi - modi di dire - proverbi del dialetto della valle di Cembra. San Michele all'Adige: Museo degli usi e costumi della gente trentina.

Battisti, Carlo (1971): I nomi locali dei comuni di lingua tedesca nell'alta Val di Non. Firenze: Dizionario toponomastico atesino. Roma; Bolzano: Istituto di Studi per l'Alto Adige,

S. 2, vol. 2, pt. 3.

Battisti, Carlo (1972): I nomi locali dell'altipiano di Lavarone-Luserna. Firenze: Olschki. Bidese, Ermenegildo (ed.) (2010): Il cimbro negli studi di linguistica. Padova: Unipress. Bonatti, Flavio (1982): Esperienze e considerazioni in relazione a una ricerca sui toponimi dei Comuni di Aldeno, Cimone e Garniga. In: Toponomastica trentina. Trento: Provincia autonoma di Trento, 239-242. 
Bonazza, Marcello (2004): La misura dei beni. Il catasto teresiano trentino - tirolese tra Sette e Ottocento. Trento: Comune di Trento.

Brida, Luciano \& Mastrelli Anzilotti, Giulia (1981): I nomi locali del comune di Caldonazzo. Trento: Società di Studi Trentini.

Del Murero, Tommaso (1890): I tedeschismi del Trentino. Rovereto: Grigoletti.

Flöss, Lydia (2002): I toponimi cimbri di Centa San Nicolò. In: Lydia Flöss (ed.), Dizionario Toponomastico Trentino. Ricerca geografica, 8. I nomi locali del comune di BosentinoCenta San Nicolò, Vattaro, Vigolo Vattaro. Trento: Provincia autonoma di Trento, Servizio Beni librari e archivistici, 44-48.

Flöss, Lydia (2009): Principali caratteristiche della toponomastica di Vallarsa con particolare attenzione ai nomi di luogo di origine tedesca. In: Lydia Flöss (ed.), Dizionario Toponomastico Trentino. Ricerca geografica, 11. I nomi locali del comune di Vallarsa. Trento: Provincia autonoma di Trento, Soprintendenza per i Beni librari archivistici e archeologici, 47-57.

Flöss, Lydia (2014): I toponimi di origine tedesca di Baselga di Piné e di Bedollo. In: Lydia Flöss (ed.), Dizionario Toponomastico Trentino. Ricerca geografica 15. I nomi locali del comune di Baselga di Piné, Bedollo. Trento: Provincia autonoma di Trento, Soprintendenza per i Beni librari archivistici e archeologici, 61-68.

Gamillscheg, Ernst (1934-36): Romania Germanica. Berlin-Leipzig, De Gruyter.

Gerola, Berengario (1932): Gli stanziamenti tedeschi sull'Altopiano di Piné nel Trentino orientale. Archivio Veneto: v. 62, n. 21-22, 1-147; n. 23-24, 129-188.

Groff, Leonello (1955): Dizionario trentino-italiano: oltre 3000 voci, frasi, detti e proverbi trentini, note sulla struttura e diffusione del dialetto. Florilegio di poesie e prose dialettali con biografie di quindici autori del Trentino. Trento: Monauni.

Lexer, Matthias (1885): Mittelhochdeutsches Taschenwörterbuch. 3. Aufl. Leipzig: Hirzel.

Lorenzi, Ernesto (1930): Toponomastica Mòchena. Trento: Scotoni.

Mastrelli Anzilotti, Giulia (1979): L'elemento tedesco nella toponomastica della Valle di Non. In: Valle del Fersina e le isole linguistiche di origine tedesca nel Trentino. S. Michele all'Adige - Trento: Museo degli usi e costumi della gente trentina, 135-145.

Mastrelli Anzilotti, Giulia (1988): Influssi tedeschi nella toponomastica trentina. In: Trentino: nomi di luogo. Trento: Provincia autonoma di Trento, 31-37.

Mastrelli Anzilotti, Giulia (1998): I toponimi di origine tedesca. In: Lydia Flöss (ed.), Dizionario Toponomastico Trentino. Ricerca geografica 5. I nomi locali dei comuni di Novaledo, Roncegno, Ronchi Valsugana. Trento: Provincia autonoma di Trento. Servizio Beni librari e archivistici, 43-48.

Melchiori, Paola (1997-8): Toponimi di origine tedesca nel comune di Folgaria. Mag. dissertation. Trento: University of Trento.

Morlicchio, Elda (1989): Germanismen im Wortschatz des Italienischen. In: Lingua Germanica. Studien zur deutschen Philologie. Jochen Splett zum 60. Geburtstag. Hg. von Eva Schmitsdorf, Nina Hartl und Barbara Meurer. Münster, New York, München, Berlin (Waxmann), 185-197.

Nocentini, Alberto (2010): L'Etimologico. Firenze, Le Monnier.

Paternoster, Mara (1996-7): Toponimi germanici nel comune di Lavarone e in alcuni comuni della Valsugana. Mag. dissertation. Trento: University of Trento.

Pellegrini, Giovan Battista (1977): Carta dei dialetti d'Italia. Pisa: Pacini.

Prati, Angelico (1960): Dizionario valsuganotto. Venezia, Roma: Istituto per la collaborazione culturale. 
Quaresima, Enrico (1964): Vocabolario anaunico e solandro. Venezia-Roma: Istituto per la collaborazione culturale.

Rowley, Anthony (1986): Fersental (Val Fèrsina bei Trient/Oberitalien): Beschreibung einer Spracheninselmundart. Tübingen: Niemeyer.

Schatz, Josef (1993): Wörterbuch der Tiroler Mundarten. 2 volumes, Innsbruck, Universitätsverlag Wagner (I edition 1955).

Schmid, Stephan \& Vigolo, Maria Teresa (1998): I tedeschismi nei dialetti della Val di Non (TN): considerazioni onomasiologiche in base al Vocabolario del Quaresima. In: Patrizia Cordin, Maria Iliescu, Heidi Siller-Runggaldier (eds.), Parallela 6: italiano e tedesco in contatto e a confronto. Trento: Università degli Studi di Trento, Dipartimento di Scienze Filologiche e Storiche, 161-178.

Tissot, Livio (1976): Dizionario primierotto: parole, frasi, modi di dire, proverbi del dialetto di Primiero. Trento: Provincia autonoma di Trento.

Valduga, Silvia (2000-01): I germanismi nel dialetto trentino. Analisi linguistica e campi semantici. Mag. dissertation. Trento: University of Trento.

Zambelli, Giulia (1996-7): Toponimi germanici nel comune di Lavarone. Mag. dissertation, Trento: University of Trento.

Zolli, Paolo (1986): Tedeschismi moderni nei dialetti italiani. In: Elementi stranieri nei dialetti italiani. Atti del XIV Convegno C.S.D.I. Pisa: Pacini, 59-77. 